\title{
РОЗВИТОК ТВОРЧОЇ ОСОБИСТОСТІ МАЙБУТНЬОГО ПЕДАГОГАЗА ТВОРАМИ ВАСИЛЯ СУХОМЛИНСЬКОГО (до 100-річчя від дня народження)
}

Michael Moore, Greg Kearsley. - Lawrence Erlbaum Associates, Inc., USA, 2007. - 368 p.

3. Borg S. The distinctive characteristics of foreign language teachers // Language Teaching Research. - 2006. - Vol.10, №1. - P.3-31.

4. Howard R., McGrath I. Distance Education for Language Teachers. A UK Perspective. - Multilingual Matters Ltd, 1995.

5. Гарбуза Т.В. Професійна підготовка майбутніх вчителів іноземної мови в системі дистанційного навчання університетів Великої Британії: дис. на здобуття наук. ступеня канд. пед. Наук: спец. 13.00.04 “Теорія та методика професійної освіти" / Гарбуза Тетяна Віталіївна; Житомирський державний університет імені Івана Франка. - Житомир, 2015. - 249 с.

6. Richards J. C. Professional Development for Language Teachers / J. C. Richards, Farrell T. S. C. Cambridge: Cambridge University Press, 2005. - 197 p.

\section{REFERENCES}

1. Polat, E. S., Moyseeva, M. V. \& Petrov, A. E. (2006). Pedagogicheskie tekhnologii distantsionnogo obucheniya [Pedagogical Technologies of Distance
Learning]. Moscow: Publishing Centre "Akademiia", 400 p. [in Russian].

2. Moore, M. \& Kearsley, G. (2007). Distance education: a system view. Boston: Lawrence Erlbaum Associates, 368 p. [in English].

3. Borg, S. (2006). The distinctive characteristics of foreign language teachers. Language Teaching Research. No. 10(1), pp. 3-31. Retrieved from: http://dx.doi.org/ 10.1191/13621688061r182oa. [in English].

4. Howard R., \& McGrath I. (1995). Distance Education for Language Teachers. Multilingual Matters Limited. Cromwell press. [in English].

5. Harbuza, T. V. (2015). Profesiina pidhotovka maibutnikh vchyteliv inozemnoi movy v systemi dystantsiinoho navchannia universytetiv Velykoi Brytanii [The professional training of future foreign language teachers in the system of distance education of Great Britain's universities]. Candidate's thesis. Zhytomyr, $249 \mathrm{p}$. manuscript copy. Retrieved from: http://eprints.zu.edu.ua/ id/eprint/17233. [in Ukrainian].

6. Richards, J. C. (2005). Professional Development for Language Teachers. Cambridge: Cambridge University Press, 197 p. [in English].

Стаття надійшла до редакції 18.12.2018

УДК 37(477)(092)“19”:37.011.3-051

DOI:

Любов Скалич, кандидат психологічних наук, доцент кафедри педагогіки та методики початкової освіти Дрогобицького державного педагогічного університету імені Івана Франка

\section{РОЗВИТОК ТВОРЧОЇ ОСОБИСТОСТІ МАЙБУТНЬОГО ПЕДАГОГА ЗА ТВОРАМИ ВАСИЛЯ СУХОМЛИНСЬКОГО (до 100-річчя від дня народження)}

У статті розглянуто позицію В.О. Сухомлинського щчодо образу вчителя, пов'язаної зокрема, з виявленням впливу особистості педагога, його професійних якостей на характер взаємин з учнями та батьками й на позицію в суспільстві. Зроблено аналіз положень з його праць, які можуть бути покладені в основу концепції іміджу сучасного вчителя, створеного В.О. Сухомлинським, та використовуватись у сучасній практииі педагогічної освіти.

Ключові слова: творча особистість; образ учителя; імідж учителя; особистість педагога; позичія вчителя в суспільстві.

Jim. 7.

Lyubov Skalych, Ph.D.(Psychology), Associate Professor of the Pedagogy and Methodology of Primary Education Department Drohobych Ivan Franko State Pedagogical University

\section{DEVELOPMENT OFTHE CREATIVE PERSONALITY OF THE FUTURE PEDAGOGUE BY THE WORKS OFVASYL SUKHOMLYNSKIY (to the 100th anniversary of the birth)}

The article examines the position of V.O. Sukhomlynskiy concerning the image of the teacher, which is associated with the identification of the influence of the teacher's personality, his professional qualities onto the nature of relationships with pupils and parents and also on the position in the society. It analyzes the basic principles of his works, they can be the basis of the concept of a modern teacher's image, created by V.O. Sukhomlynskiy; and they can be used in the modern practice of pedagogical education.

The article considers the vision of the aim of education by the teacher in the comprehensive development of personality, its value is revealed. The examples of indicators of personality's breeding are presented. The emphasis is placed on the formation of the future teachers' self-respect. The position of a teacher in the society is investigated; V.O. Sukhomlynskiy devoted many thoughts to the person of a teacher.

The ways of the use of the scientist's pedagogical heritage in the development of the creative personality of 


\section{РОЗВИТОК ТВОРЧОЇ ОСОБИСТОСТІ МАЙБУТНЬОГО ПЕДАГОГАЗА ТВОРАМИ ВАСИЛЯ СУХОМЛИНСЬКОГО (до 100-річчя від дня народження)}

the future pedagogue are determined. The article reveals a great role of the education as an organized, purposeful process in the formation of personality. It thoroughly analyzes the tasks, content and methods of the components of national education, in particular the need for the pupils' education in work.

A detailed analysis of the child's emotional world is given; the emphasis is placed on the formation of primary schoolchildren's self-esteem.

The article notes that school life should be accompanied by joy, feeling of success, optimism, humaneness, respect. It analyzes the negative manifestations of humiliation of children, insults, which still occur in the educational process of primary school. Vasyl Sukhomlynskiy repeatedly wrote about them in his works. the society.

Keywords: creative personality; the image of the teacher; personality of the teacher; the teacher's position in

П

остановка проблеми. Українську і світову педагогіку сьогодні вже неможливо уявити без імені Василя Олександровича Сухомлинського. Педагогічна практика сільського вчителя і педагогічна теорія науковця відомі далеко за межами України. Праці педагога, його ідеї, інтелект і почуття й сьогодні допомагають педагогам-практикам та науковцям, - всім, кого цікавлять проблеми виховання навчання.

Образ учителя глибоко хвилював видатного педагога-гуманіста В.О. Сухомлинського, причому він вважав, що з учителя починається пізнання дитиною світу людини. Учитель, на його думку, - це скульптор, який творить людину майбутнього, причому скульптор особливий, не схожий на інших. Виховання - творення людини становить суть професії вчителя. Суспільство дивиться на вчителя як на професійного творця особистості, як на майстра-скульптора, від якого величезною мірою залежить майбутнє нашої країни.

Аналіз останніх досліджень і публікацій. АналізупедагогічноїдіяльностіВ.О. Сухомлинського присвячені дисертаційні дослідження Г.В. Калмикова, І.І. Буєвої, Ю.Г. Новгородської та інших. Питанням вивчення образу вчителя присвячені дисертаційні дослідження М.Н. Фреловської, Н.Д. Дудіної, С.П. Ільїної та інших.

Мета статті полягає у визначенні шляхів використання педагогічної спадщини В.О. Сухомлинського у розвитку творчої особистості майбугнього педагога.

Виклад основного матеріалу. Аналізуючи педагогічну спадщину В.О. Сухомлинського, можна виділити кілька напрямів у творенні ним образу педагога: особистість вчителя, його професійні якості, характер взаємин 3 учнями, батьками, позиціонування вчителем себе в суспільстві.

Коло дослідницьких проблем, що знайшли відтворення в творчості В. Сухомлинського, надзвичайно широке та багатоаспектне. Важко назвати те, що не піддавалось аналізу в його дослідженнях. Він глибоко вивчав питання розумового, морального, патріотичного, трудового, естетичного, фізичного виховання учнів. Предметом уваги науковця було сімейне виховання, чому спеціально присвячувалась книга "Батьківська педагогіка". Самовиховання і самоосвіта, методика виховання в колективі і педагогічна культура вчителя, професійна майстерність педагога і роль природи у вихованні, почуття дітей i методика вивчення учнів педагогом, особливості керівництва школою та багато інших питань знаходили переконливе розкриття в творах видатного педагога. У дослідницьких пошуках він звертався не тільки до відомої, усталеної тематики, а й до такої, що не знаходила місця серед них, наприклад: "Гумор у духовному житті колективу”, “Радість і доброта, сила і совість у дитячому колективі”, “Чоловіки і жінки в колективі”, "Мудра влада педагога над особистістю й колективом" та інші.

Численні праці В.О. Сухомлинського розкривають глибокий світ його педагогічних ідей. Видатний педагог визнавав велику роль виховання як організованого, цілеспрямованого процесу у формуванні особистості. Цю думку важливо загострити в наш час, оскільки інколи зустрічається намагання послабити ознаки організованості виховної діяльності, а відсугність чітких засад у її здійсненні пов'язати 3 демократизацією виховання. Такий підхід суперечить поглядам В. Сухомлинського, який в праці “Серце віддаю дітям” писав: “Я твердо вірю в могутню силу виховання" $[5,8]$. У багатьох творах він розкриває такі засади організації виховання як його мета, завдання, зміст, принципи і методи здійснення тощо.

Мету виховання видатний педагог вбачав у всебічному гармонійному розвитку особистості. Досягнення загальної мети виховання він розглядав через здійснення різних складових частин виховного процесу, які у своїй сукупності ведуть до цілісного формування всебічно розвиненої особистості, ії багатства. Вчений дуже грунтовно аналізував завдання, зміст і методику розумового, фізичного, морального, трудового, естетичного виховання.

До показників вихованості особистості він 


\section{РОЗВИТОК ТВОРЧОЇ ОСОБИСТОСТІ МАЙБУТНЬОГО ПЕДАГОГАЗА ТВОРАМИ ВАСИЛЯ СУХОМЛИНСЬКОГО (до 100-річчя від дня народження)}

відносив іï гуманність, любов до Батьківщини, громадянськість, любов і прагнення до знань, допитливість, самостійність думки, працьовитість, естетичне сприйняття світу, фізичну досконалість, вольові зусилля, мужність, наполегливість, щирість тощо [1, 175].

Педагогічні погляди В. Сухомлинського 3 питань всебічного розвитку особистості варто знати і творчо втілювати в життя педагогу при розбудові національної системи виховання.

Важливою є думка видатного педагога, що гармонія всіх людських граней і рис визначається чимось провідним, основним визначальним компонентом у цій гармонії є моральність”, писав він $[2,105]$. Усе, що робиться в школі, повинно мати глибокий моральний зміст, сприяти формуванню моральної культури особистості. Суттєвий елемент моральної культури - засвоєння загальнолюдських норм моральності, які В. Сухомлинський назвав азбукою моралі [7, 120]. До змісту азбуки моралі педагог-гуманіст відносив ставлення людини до Батьківщини і своїх обов'язків, до батьків, рідних, близьких і всіх людей, до школи, вчителя, знань, природи, краси, до понять життя, добра, зла, дружби, любові, сім’ї. Азбука моралі - це практичний вияв моральних якостей і норм поведінки [7, 121].

У зв'язку з оволодінням азбукою моралі перед учнями розкривається суть найвищих моральних цінностей: Людина - найвища цінність, любов до Вітчизни, героїзм, гуманізм, працьовитість, культура спілкування та інші. Особливу цінність для педагогів-практиків складають своєрідні моральні заповіді для дітей, розроблені В.О. Сухомлинським, вміщені у праці “Як виховати справжню людину".

Всебічно уявляв В. Сухомлинський завдання розумового виховання: "Розумове виховання передбачає набуття знань і формування наукового світогляду, розвиток пізнавальних і творчих здібностей, вироблення культури інтелектуальної праці, виховання інтелектуальної праці, виховання інтересу і потреби в розумовому збагаченні протягом усього життя, в застосуванні знань на практиці" $[6,110]$. Він розкривав значення різних навчальних предметів для формування особистості і зазначав, що кожний повинен бути в певній мірі і математиком, і фізиком, і хіміком, i біологом, і істориком, і літературознавцем - у такій мірі, в якій це необхідно для всебічного розвитку $[6,120]$. Особливо наголошував видатний педагог на необхідності розвитку інтелекту дітей, їх гнучкої, живої, допитливої творчої думки. Людина повинна вміти щось довести, ствердити, відстояти свою позицію.
Розумова праця учнів має носити дослідницький характер, сприяти повноті духовного життя, спрямовувати на сприйняття культурних, естетичних цінностей.

Василь Олександрович дав багато цінних порад учителям та учням щодо розумового виховання. Кожен учень має свої особливості, інтелектуальні здібності. Немає абстрактного учня. Навчання - дуже серйозна праця, воно не повинно перетворюватись у зубрячку. Слід забезпечити інтерес учнів до навчання, збудити ïх інтелектуальні зусилля, активність думки. В початкових класах дуже важливим $є$ формування в учнів навичок читання й письма, вміння правильно вчитись. Мислення тісно пов'язане 3 словом, мовою. Засвоєння учнями рідної мови має неоціненне значення. Мова - знаряддя пізнання i виховання. Любов до Батьківщини - неможлива без любові до рідного слова. Навчання має давати радість пізнання. У численних його працях педагог знайде для себе багато повчального щодо розумового виховання дітей. Варто для цього навести зразки тільки деяких заголовків із праці “Сто порад учителеві”: “Про збереження в пам'яті школяра елементарних знань”, “Дві програми навчання”, “Розвиток мислення школяра”, “Знання - і мета, і засіб”, “Про добування знань”, “Як вести учнів від фактів до абстрактних істин”, “Перше вивчення матеріалу”, “Оцінки мають бути вагомими”, "Мати навчання не повинна стати мачухою”, “Зміст активної діяльності учнів під час вивчення предмета”, “Як розвивати мислення й розумові сили дітей”, “Як виховувати пам'ять" [6].

Провідною ідеєю в творчості В. Сухомлинського виступає думка про необхідність виховання дітей в праці: “Трудове життя в роки дитинства, отроцтва і ранньої юності - одна з важливих умов формування гармонійної людини" [6]. Для В. Сухомлинського виховання в праці - це перш за все виховання любові до праці. Дитина прагне працювати тоді, коли праця дає їй радість. Радість праці - могутня виховна сила. Але це не означає, писав В. Сухомлинський в книзі “Серце віддаю дітям”, що праця перетворюється в розвагу. Праця вимагає напруження, настирливості: “Радість праці й гордість за наслідки праці приходять лише до тих, хто матеріальні наслідки здобув нелегким зусиллям, хто землю зросив потом..." [5, 204]. Залучати дитину до праці слід з ранніх років, керуючись народною мудрістю: 3 того часу, як дитина навчилася нести ложку від миски до рота, вона мусить працювати. Важливо, щоб в роки дитинства людина на власному досвіді збагнула істину, що праця творить гідність особистості і 


\section{РОЗВИТОК ТВОРЧОЇ ОСОБИСТОСТІ МАЙБУТНЬОГО ПЕДАГОГАЗА ТВОРАМИ ВАСИЛЯ СУХОМЛИНСЬКОГО (до 100-річчя від дня народження)}

дає моральне право судити про інших людей.

В. Сухомлинський рекомендував включати дітей в різні види праці, методично правильно її організовувати (враховувати вік дітей, ї інтереси, забезпечувати культуру праці, формувати трудові вміння та навички як основу в досягненні успіху).

Слід поєднувати виконання трудових завдань iз творенням прекрасного, відчуттям краси. Без виховання красою В. Сухомлинський взагалі не уявляв виховання. В книзі “Як виховати справжню людину” він писав: “Краса - це радість нашого життя. Людина стала Людиною тому, що побачила глибину блакитного неба, мерехтіння зірок, рожевий розлив вечірньої зорі, прозорий серпанок степових просторів, червоний захід сонця вітряним днем...”. До завдань естетичного виховання Сухомлинський відносив розвиток у дітей сприйняття прекрасного, формування естетичного ставлення до дійсності, практичне творення прекрасного і вважав, що воно має найтісніші зв'язки $з$ усіма сферами духовного життя особистості. До важливої передумови багатства естетичних потреб і переживань особистості ним

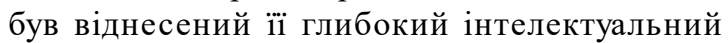
розвиток: "Поверхові знання і закостеніння думки - перший ворог естетичного виховання" [7, 177]. Але сам по собі обсяг і глибина знань не свідчать про естетичні оцінки різних явищ життя. Тому 3 перших днів шкільного навчання слід виховувати в дітей вміння бачити, сприймати, відчувати, розуміти красу природи і суспільних відносин. Педагог звертав увагу педагогів до думки: “Сприймання, осмислення прекрасного - це основа, стрижень естетичної освіченості, серцевина тієї естетичної культури, без якої почуття залишаються глухими до всього благородного і високого в житті" [7, 178]. Засоби естетичного виховання різноманітні: література, музика, живопис, природа, естетика оточення, людини, відносин, праці. Видатний педагог писав: “Те, що неможливо передати словом, можна сказати гармонією фарб, мелодією”; “Краса мати добра і сердечності”; “... краса слова - це іскра, яка запалює вогник думки” [7, 179; 183]. Учнів слід постійно залучати до активного творення прекрасного. Це має особливо важливе значення у молодшому віці.

Предметом постійної турботи В. Сухомлинського були питання фізичного виховання учнів. У праці “серце віддаю дітям” заголовок одного з розділів він назвав “'Здоров'я, здоров'я і ще раз здоров'я” $[5,103]$. Він вважав, що турбота про здоров'я це найважливіша праця вихователя, бо від бадьорості дітей, життєрадісності залежить їх духовне здоров'я, світогляд, розумовий розвиток, віра в свої сили. Шляхи здійснення цього завдання - режим, правильне, повноцінне харчування, використання сонця, повітря, води, рухів, гри, фізичної праці тощо. У кожного учня необхідно сформувати свідоме ставлення до власного організму, виробити вміння берегти і зміцнювати здоров'я.

В багатій спадщині В. Сухомлинського детальний аналіз дається емоційному світу дитини. Важко назвати іншого педагога, який би стільки уваги приділив ролі емоцій в навчальновиховному процесі. Він вживав термін “емоційна товстошкірість” і одним з найважливіших завдань виховання вважав розвиток інтелектуальних, моральних, естетичних та інших почуттів дітей. Шкільне життя має супроводжуватись радістю, переживанням успіху, оптимізмом, гуманністю, доброзичливістю, повагою, сумлінням тощо. Неприпустимими $є$ учнівський страх, приниження дітей, образи, нудьга та інші негативні прояви, які ще мають місце в навчально-виховному процесі. Особливий акцент видатний педагог зробив на формуванні в учнів почуття власної гідності: “Я завжди прагнув до того, щоб у кожного вихованця на все життя утвердилась самоповага, здорове самолюбство, нетерпимість до грубих, безтактних відносин між людьми... Повага до себе - емоційний стан, який мусить бути загальним, всеосяжним, духом школи" [5, 271].

Велика роль у створенні такого духу школи відводилась В. Сухомлинським учителю. Особі вчителя присвячено багато його думок. Читач зустрічає в працях видатного педагога розгляд таких питань, які іншими науковцями майже не досліджувались: чоловіки й жінки в колективі, гумор у духовному житті, мудра влада педагога над особистістю і колективом та інші $[5,120]$. Педагог застерігав від неправильного розуміння педагогом своєї влади над дитиною. Мудрість влади дорослої людини над дитиною - це велика творчість, глибоке сердечне проникнення в світ дитячих думок і почуттів, це вміння розуміти мову дитинства, зберегти в собі краплю дитинства i водночас не стати на одну дошку 3 дитиною за рівнем розвитку. Влада педагога має бути обережною, адже воля старшого може легко перетворитися в сваволю. "Не придушити й зламати, а підняти й підтримати, не знеособити внутрішні духовні сили дитини, а утвердити почуття власної гідності - тільки так треба здійснювати свою владу над дитиною, і тільки за цієї умови ваша влада може бути мудрою”, писав В. Сухомлинський [6, 643].

Висновки. Отже, багата науково-педагогічна спадщина видатного педагога - це результат його 
плідної практичної роботи і невтомного дослідництва, що випливало з самого життя і не було надуманим. Вона - неоціненне джерело для успішної професійної діяльності кожного вчителя, а також для розвитку творчої особистості майбутнього педагога.

Перспективу подальших досліджень вбачаємо у вивченні творів В.О. Сухомлинського у практиці сучасної підготовки майбутніх учителів.

\section{ЛІТЕРАТУРА}

1. Богуш А.М. Педагогічні виміри Василя Сухомлинського в сучасному освітньому просторі: монографія / А.М. Богуш. - К.: Видавничий дім “Слово”, 2008. - 272 с.

2. Сараєва О. Учитель у педагогічній системі В.О. Сухомлинського / О. Сараєва // Науковий вісник МДУ. Педагогічні науки. Зб. наук. праць. - Вип. 8. - Миколаїв, 2004. - С. 104 - 108.

3. Савченко О.Я. Виховний потенціал початкової школи / О.Я. Савченко. - К., 2009. $225 \mathrm{c}$.

4. Сухомлинський В.О. Казки. Оповідання. Етюди / Упоряд. О.В. Сухомлинська. - К.: Генеза, 2003. -270 c.

5. Сухомлинський В.О. Серце віддаю дітям / В.О. Сухомлинський. - К.: Радянська школа, 1981. $-398 \mathrm{c}$.

6. Сухомлинський В.О. Сто порад учителю / В.О. Сухомлинський. - К.: Радянська школа, 1988. $-304 \mathrm{c}$.

7. Школа першого ступеня. Теорія і практика. Культурологічні засади педагогічної спадщини В.О. Сухомлинського: Зб. наук. праць ПереяславХмельницького ДПУ ім. Г. Сковороди. Тернопіль: Астон, 2007. - 302 с.

\section{REFERENCES}

1. Bohush, A. M. (2008). Pedahohichni vymiry Vasylia Sukhomlynskoho v suchasnomu osvitnomu prostori: monohrafiia [Pedagogical measurings of Vasyl Sukhomlynsky in the modern educational space: monograph]. Kyiv: Vydavnychyi dim "Slovo", 272 p. [in Ukrainian].

2. Saraieva, O. (2004). Uchytel u pedahohichnii systemi V.O. Sukhomlynskoho [Teacher in the pedagogical system of V.O. Sukhomlinsky]. Scientific herald of Mykolayiv State Unsversity. Pedagogical sciences a collection of sciences works, vol. 8, pp. 104-108. [in Ukrainian].

3. Savchenko, O. Ia. (2009). Vykhovnyi potentsial pochatkovoi shkoly [Educational potential of primary school]. Kyiv, 225 p. [in Ukrainian].

4. Sukhomlynskyi, V. O. (2003). Kazky. Opovidannia. Etiudy [Tales. Stories. Etudes]. (Ed.). O.V. Sukhomlinska. Kyiv: Geneza Publ., 270 p. [in Ukrainian].

5. Sukhomlynskyi, V.O. (1981). Sertse viddaiu ditiam [I give my heart to the children]. Kyiv: Radianska shkola, 398 p. [in Ukrainian].

6. Sukhomlynskyi, V.O. (1988). Sto porad uchyteliu [One hundred advices to the teacher]. Kyiv: Radianska shkola, 304 p. [in Ukrainian].

7. Shkola pershoho stupenia. Teoriia i praktyka. Kulturolohichni zasady pedahohichnoi spadshchyny V.O. Sukhomlynskoho (2007). [School of the first degree. Theory and practice. Cultural fundamentals of pedagogical heritage of V.O. Sukhomlinsky]. A collection of sciences work of PereyaslavKhmelnytskiy Hryhoriy Scovoroda State Pedagogical University. Ternopil: Aston Publ., 302 p. [in Ukrainian].

Стаття надійшла до редакції 05.12.2018

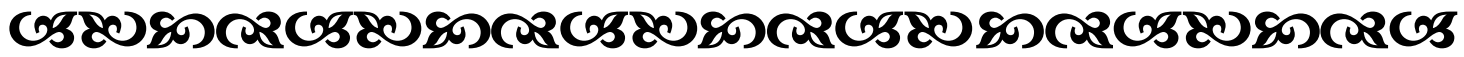

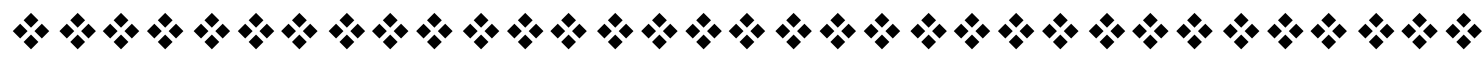

"Учитель, який хоче мати високі результати навчання, повинен знати стилі пізнання своїх учнів, поқладати це в основу організації спільнї діяльності педагога $i$ школарів на уроиі”.

“Справжній педагог повинен прачювати на майбутнє”.

“भјоб бути Великим - треба бути людиною. Великої ідеї та великого характеру”. Василь Сухомлинський педагог, публічист, письменник

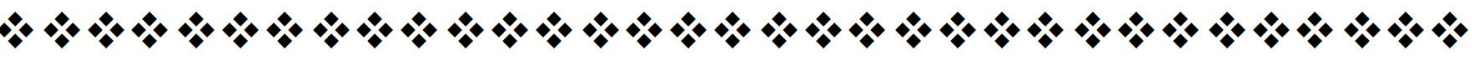

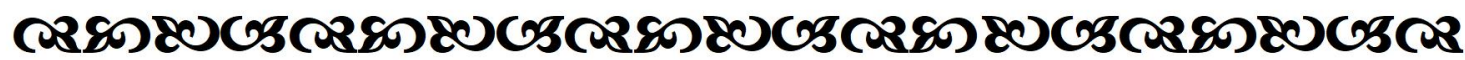

